biological attributes of the class (' aliis metamorphosin subire'). But however this may be, the name was first limited to the forms undergoing metamorphosis by De Blainville, and there is no reason why that restriction should not be respected.

The name Batraciens, or Batrachia, was given as an ordinal name., It was not used as a class name till long after Amphibia had been duly restricted to the class still so called.

If the name Batrachia were usable at all it should only be as an ordinal designation, as Huxley has done. But it cannot be legitimately used as such, because many years before the name Salientia had been introduced by Laurenti for the same order, and most of the best herpetologists of the present time (Cope, Boulenger, et al.), have revived or accept the name for the order so designated.

The name Amphibia was first used as a class name by Linnæus for a group which was certainly very heterogeneous, inasmuch as it included not only the typical Amphibians and reptiles, but also the Marsipobranchs and Selachians, as well as certain true fishes (Lophius, Acipenser, etc.). The class was divested of the fish-like forms by the editor of the Systema Naturæ (Gmelin, 1788), and with these limits it was long retained.

The essential point in the case under consideration is that Linnæus first recognized a class intermediate between fishes and birds, whose typical representatives pass part of their life in water and part on land, and the apt name Amphibia was given to that class. (The name is eminently suggestive and expressive for the class as now limited.) Batrachia was given long afterwards both as an ordinal and class des. ignation. (The name is quite inapt for many, of the species.)

Theo. GILL.

\section{SURVIVAL OF THE ART OF ILLUMINATING MANUSCRIPTS AMONG THE GERMANS IN EASTERN PENNSYLVANIA.}

AMONG the interesting objects included in the collection of tools, utensils and paraphernalia, representing the life of the American pioneer, recently made for the Historical Society of Bucks County, Pennsylvania, two curious paint boxes, for a time defying explanation, have at last led to an interesting observation. By degrees, after a series of investigations, beginning on August 20th, I learned that these boxes had contained, in their wooden compartments, the paints and colored inks by which the masters of the German schools in upper Bucks County (discontinued about 1850), taught the art of Fractur, or illuminative handwriting done in colors for permanent preservation. The liquid colors mixed in whiskey were contained in the little glass bottles still occupying their pigeon holes in one of the boxes. Other bottles contained inks, and one the varnish, consisting of the gum of the cherry tree diluted in water. A long compartment held the brushes and quill pens.

With these implements the masters of Fractur, generally Mennonites (who sometimes instructed pupils in the art as an addition to the ordinary tuition of a schoolmaster), illuminated the title pages of numerous Mennonite manuscript song books still extant in the county, produced elaborate title pages for Bibles, name cards, marriage and death registers, and Scriptural texts. A striking example in the possession of Henry K. Gross, of Doylestown, is a transcription of the 18th verse of the 19th chapter of John with decorated letters and floriated capitals in red, green, brown, blue and black, set above a bar of music, and twelve lines of cursive manuscript, upon which are placed two birds in red, green and black. A pious admonition in red and black text edges transversely the left end, while the lower margin is filled with an alphabet in various text. The borders are floriated and plain red or blue.

Further examples are: A, Title page to Church song book (Lieder Buch, printed in Germantown, by Michael Villmeyer, in 1811), name Susanna Fretz upon heart, from which springs a tree with conventional tulips; deep beaded borderings, 1814, colors red, brown, yellow and black, red predominant. B, Title page to manuscript song book, name Susanna Fretz (spelled Fretzin for feminine) in red circle with date 1810 ; stalks with black leaves and conventional tulips to right and left; foliated border with red leaves on black and yellow ground. C, Title page to manuscript hymmbook; name, 
Joseph Gross, illuminated letters, foliated capitals; date, April 20, 1830 ; double tulips in foliate on yellow ground. D, Title page to manuscript hymn book, name Sarah Wismer; foliated capitals, conventional flowers on heavy stalks; date 1827 ; colors red, yellow, brown and blue. E, Title page to ditto; name, Elizabeth Nesch (Neschin), with words Dieses SingNoten Buchlein Gehoret Mir; Sing Schuler In Der Bedminster Schule; Geschrieben September 6-ten im Jahr 1799, with three tulips and several colors. Other examples are within easy

\section{REMARKABLE HAILSTONES.}

ABout 5 o'clock in the afternoon of August 10th I was at Manassas depot, in Prince William County, Va., near the famous battlefield, waiting for a train. There was some pretty severe thunder and lightning for a half hour or so, and then came a heavy shower of rain, during which there was the most remarkable fall of hail I have ever witnessed. I hurried out in the rain to examine the stones and picked up several. These were nearly square flattish blocks, say from $\frac{3}{4}$ to 1 inch in length and

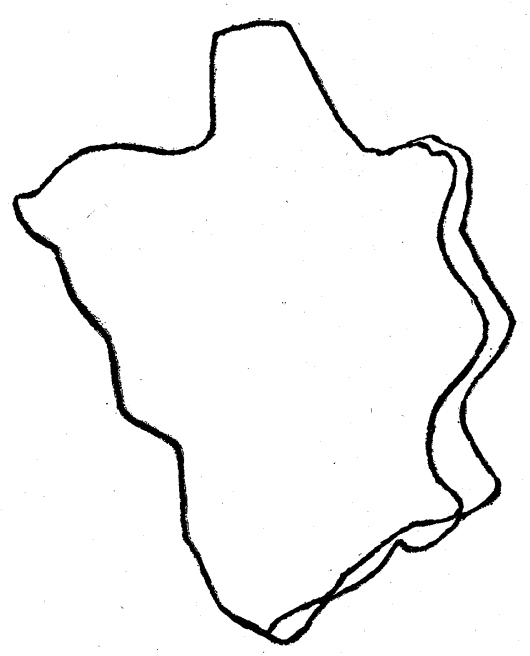

FIG. 1.

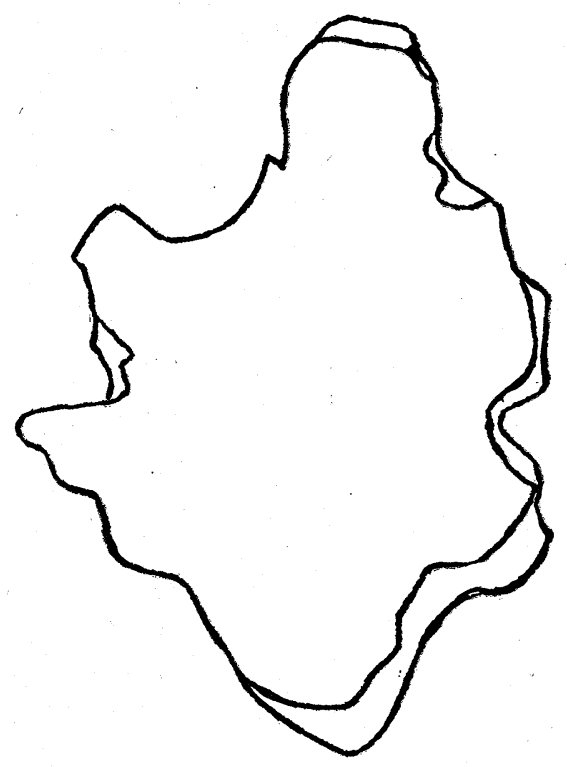

FIG. 2.

Outline of Hailstones that fell at Manassas, Va., August 10, 1897.

reach of the writer. And it has appeared evident that the art thus preserved by Mennonites in a remote part of Bucks County until about 1850 , and represented by the old paint boxes in possession of the Historical Society, is a survival in America of the mediæval art of manuscript illumination. Much more remains to be said upon this subject which reveals the early relation of Germany to the United States in one of its most interesting aspects.

\section{Henry C. Mercer.}

INDIAN House, August 30, 1897. breadth, and from $\frac{1}{4}$ to $\frac{1}{2}$ an inch in thickness. They suggested, by both shape and size, the ordinary 'chocolate caramels,' of the confectioner. There were some 8 or 10 persons, I think, in the station house with me, and several of these, observing my interest and enthusiasm, began to pick up the larger stones and bring them in to me and to to my friend, Professor Hargrove, of Luray, Va. Soon larger and larger ones were thus collected, and I sought for means of measuring or weighing them. No rule or scales could be found, and 